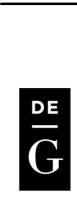 \\ DE GRUYTER
OPEN \\ DOI 10.2478/v10129-011-0071-5 \\ ${ }^{1}$ M.A .Adebisi, ${ }^{1}$ O.A. Esuruoso, ${ }^{2}$ J.A .Adetumbi, ${ }^{3}$ A.M. Abdul-Rafiu, \\ ${ }^{1}$ T.O. Kehinde, ${ }^{1}$ O.O. Ajani, ${ }^{4}$ D.A. Agboola,
}

${ }^{1}$ Department of Plant Breeding and Seed Technology, Federal University of Agriculture, Abeokuta, P. M. B. 2240, Abeokuta, (FUNAAB) Ogun State, Nigeria; ${ }^{2}$ Institute of Agricultural Research and Training, P.M.B.5029, Moor Plantation, Ibadan, Nigeria; ${ }^{3}$ Seed Technology Unit, National Horticultural Research Inst., P.M.B. 5432, Ibadan, Nigeria; ${ }^{4}$ Department of Biological Science, Federal University of Agriculture, Abeokuta, P. M. B. 2240, Abeokuta, Ogun State, Nigeria; e-mail: mayoadebisi@yahoo.co.uk

\title{
SHELF LIFE OF KENAF (HIBISCUS CANNABINUS L.) SEED STORED UNDER HUMID TROPICAL CONDITIONS
}

\begin{abstract}
Successful crop production depends initially on the availability of high-quality seed. Seed viability and vigour of four kenaf varieties during storage were investigated. Seeds of each variety were packed inside thick polythene bags and kept in Seed Stores under ambient conditions in two storage locations (Federal University of Agriculture, Abeokuta (FUNAAB) $\left(29.8^{\circ} \mathrm{C}, 59.10 \mathrm{RH} \%\right)$ and Institute of Agricultural Research and Training, Ibadan $\left(27.5^{\circ} \mathrm{C}, 64.68 \mathrm{RH} \%\right)$ for 240 days ( 8 months). Seeds were sampled during storage at $0,60,120$, 180 and 240 days and tested for seed viability and seedling vigour index. Data collected on seed viability and seedling vigour were analyzed using ANOVA, mean separation using Duncan Multiple Range Test at 5\% probability level and PROBIT analysis. The results showed differential responses in the two quality traits due to differences in storage location and varieties. Ibadan storage location provided more favourable conditions for higher seed quality compared to Abeokuta location while Ifeken 400 and Tianung had the best storage potential. The study showed that under ambient humid tropical conditions, storage period should not exceed 180 days (6 months) in order to maintain higher physiological quality with little or no cost. The PROBIT result revealed that the highest seed shelf life (longevity) of kenaf seeds of 8 to 9 months was derived for seeds of Ifeken 400 and Tianung stored in Ibadan and Abeokuta. The shortest shelf life of 6 months was estimated for Ifeken 100 stored in both locations.
\end{abstract}

Key words: probit modelling, storage life, seed quality, seed viability, seedling vigour

Communicated by Ryszard Górecki 


\section{INTRODUCTION}

In Nigeria, kenaf (Hibiscus cannabinus L.) is a drought resistance crop with relatively wide range of adaptation, which ranges from wide range of soil types, good tolerance to salinity, water stress and logging. It's susceptible to climate extremes and to pests and diseases (Aimin, 2006). Kenaf is a veritable source of making strong ropes for drawing water from wells. Due to its extensive and multifarious uses, kenaf has remained one of the most useful materials to both local farmers and agro-allied industrialists.

However, owing to its numerous uses, many attractive incentives were offered to farmers in Nigeria to encourage them to grow the crop. But the crop subsequently witnessed a set back because the interest of farmers to grow kenaf diminished as a result of instability of market prices and apparent glut in the market due to serious competition with imported product. In recent times, rehabilitation of kenaf production, processing and utilization is on increase, but there is a problem of low quality seed available for the farmers due to lack of information on kenaf storage physiology.

Longevity of seeds in storage is a good indicator of seed viability and vigour in many crops (Ellis and Robert, 1980; Robert 1983; Adebisi et al., 2003 and Adebisi et al., 2008). It is already well known that seed longevity is a function of storage temperature and seed moisture content (Harrington, 1972; Roberts, 1973), stress before seed storage and initial seed quality (Ellis and Roberts, 1980), genetic male-up (Adebisi et al., 2004) and pest and pathogen damages in storage.

Seeds are stored for few days, weeks, months or year during which it deteriorates, moving inexorably towards death (Greg et al., 1994). Kenaf seeds, being high in oil content, are prone to seed deterioration if improperly kept. Maintenance of vigour and viability in oil seeds is a major constraint to kenaf production particularly under unfavourable conditions of storage. Even in good storage, the signs of physiological deterioration in terms slower germination and reduced seedling growth of carry-over seeds are apparent (Ramamothy, 1989). However, even when care is taken during storage, deterioration occurs at variable speed and intensity, according to the initial physiological quality of the seeds and the storage environment. Such differences have been revealed in the storability of soybean (Thseng et al., 1996), Nkang and Umoh 1996; Adebisi et al., 2004; Akintobi et al., 2006). The ability to forecast seed deterioration is enormous for the proper management of seed longevity in stores and germplasm repositories loss in seed quality as well as deterioration. It also helps in decision supports in the gene bank management. Robert (1973) developed model based on negative 
cumulative normal distribution pattern of seed deterioration at specified storage conditions.

Kenaf production in south west Nigeria is hampered by the speed with which the seed lose their viability when expose to warm, moist air that characterizes ambient humid climate. To arrest the rapid rate of seed deterioration under the prevailing adverse storage conditions, seeds are maintained in dry cool condition store for conservation of genetic resources, a facility that is expensive, uneconomical and unaffordable by the poor resource farmers. This renders kenaf seed storage an expensive venture. Hence, it is imperative to determine the storage life of kenaf seed under the prevailing ambient conditions in south-western, Nigeria for better management of kenaf genetic resources.

The objectives of the study, therefore, were to determine the effect of storage duration on viability and seedling vigour of seeds of four kenaf varieties stored under ambient storage conditions and to estimate seed longevity of four kenaf varieties under ambient storage conditions using probit modelling.

\section{MATERIALS AND METHODS}

\section{Seed Materials}

Four kenaf varieties (Ifeken 100, Cuba 108, Tianung and Ifeken 400) obtained from the freshly harvested seed at the Seed Unit of Institute of Agricultural Research and Training (IAR\&T), Moor plantation, Ibadan were utilized for this study. Ifekan 100 and 400 are local varieties while Cuba 108 and Tianung are exotic varieties. These varieties are commonly grown in Nigeria and they have been found to be promising with high fibre and seed yield. Nothing was known about the storage performance of these varieties.

\section{Initial Seed Quality Assessment}

Freshly harvested seed samples from each variety were further cleaned, sorted and tested for initial seed quality (seed germination and moisture content). Germination test was performed on three sub-samples of 100 seeds placed in a paper towel moistened with $10 \mathrm{mls}$ of distilled water inside $11 \mathrm{~cm}$ diameter Petri-dishes and germinated at $25^{\circ} \mathrm{C}$ in an incubator (Table 1). Percent germinated seed were determined after 7 days (ISTA, 1995), and the following results were recorded; Ifeken 100 (78\%); Tianung (76\%), Cuba $108(80 \%)$ and Ifeken 400 (75\%). Also initial seedling vigour index was also calculated using Kim et al. (2002) formula and seedling vigour values of $35.6,35.5,34.2$ and 33.8 were recorded for Ifeken 100, Cuba 
108, Tianung and Ifeken 400 respectively. Moisture content (MC) was determined using John Wilkey apparatus of determination of seed moisture. A $200 \mathrm{~g}$ seed of each variety in two replicates were placed into the apparatus cup and seed moisture content values were recorded in percentages. The MC ranged from $10.5 \%$ for Cuba 108 to $11.3 \%$ for Ifeken 100 while Ifeken 400 and Tianung had MC of 11.0 and $10.8 \%$ respectively.

Experimental Design

The study was a factorial experiment in a completely randomized design with three factors (storage location, variety and storage durations). There were 64 treatments (two storage locations, four varieties and eight storage durations) which were replicated three times.

\section{Seed Storage}

Seeds of each variety were divided into two seed lots of $400 \mathrm{~g}$ each. Each seed lot was placed inside thick polythene bags ( 15 x 15 sizes) and then heat sealed. The first packaged seed lots of the four varieties were kept in Seed Store in the Seed Processing and Storage Building of the Federal University of Agriculture, Abeokuta (UNAAB) (Latitude $7.1^{\circ} \mathrm{N}$ and Longitude $\left.3.2^{\circ} \mathrm{E}\right)$, Ogun State, Nigeria under ambient conditions $\left(29.8^{\circ} \mathrm{C}, \mathrm{RH}=\right.$ $59.10 \%$ ) for 240 days ( 8 months). The second seed lots were kept in Seed Store of the Institute of Agricultural Research and Training (IAR\&T), Moor Plantations, Ibadan $\left(7.30^{\circ} \mathrm{N}, 3.54^{\circ} \mathrm{E}\right)$, Oyo State, Nigeria under ambient conditions $\left(27.5^{\circ} \mathrm{C}, \mathrm{RH}=64.68 \%\right)$ for the same period. The study duration was 8 months between April and December, 2007.

\section{Seed Quality Assessment}

Seed samples were taken from each polythene bag from each storage location for seed quality evaluation at 30-day interval for a period of 240 days. Sampled seeds were then subjected to following laboratory tests:

\section{Seed viability}

Seed germination test was used to determine viability of the seeds. Three sub -samples of 100 seeds were placed on moisture paper towel with $10 \mathrm{ml}$ of distilled water inside petri-dishes and germinated at $25^{\circ} \mathrm{C}$ in an incubator at the laboratory of Department of Plant Breeding and Seed Technology, FUNAAB. Germination count for normal seedlings was expressed as percentage viable seeds for each variety.

\section{Seedling Vigour Index (SVI)}

The test was carried out together with the germination test previously described. Five normal seedlings were randomly selected from a replicate 


$$
S V I=\frac{\text { Percentage Viability }[\%] \times \text { Seedling Length }[\mathrm{cm}]}{100}
$$

for measuring seedling length. Seedling vigour index (SVI) was then calculated using Kim et al. (1994) formula as reported by Adebisi, (2004) thus:

\section{Data Analysis}

Data on seed viability involving percentage were transformed using angular transformation $\left(\operatorname{arcsine}=\sqrt{ } \operatorname{Sin}^{-1}\right)$. Analysis of variance was computed on each of the two traits and significance treatment means were determined based on Duncan multiple range test at 5\% probability level (Duncan, 1955). In order to predict the storage life of the seeds, PROBIT analysis was carried out on seed viability data obtained in the study.

The PROBIT analysis of mean percentage seed viability data was done with SASTM PROC PROBIT statements that first sorted the data by variety and storage location. Seed viability parameters were estimated from the procedure based on eight viability test data point for each location. Estimates of intercept (time $=0$ ) of the seed survival line, slope i.e. rate of seed determination $(l / s)$ and time taken for seed ageing to decline to $50 \%$ viability $\left(P_{50}\right)$ were estimated by the PROBIT procedure for each seed lots. Seed shelf life was estimated as half life $\left(P_{50}\right)$ value multiplied by 2 then divided by the 30 days of a month.

\section{RESULTS}

Results in Table 1 show the summary of analysis of variance for seed viability, field emergence and seedling vigour index evaluated under two storage locations and eight storage periods in four kenaf varieties. The data showed that the effects of storage, location, storage duration, and variety were highly significant $(\mathrm{P} \leq 0.01)$ on seed viability and field emergence. However, the effect of storage duration was highly significant on the seedling vigour index whereas location and variety recorded non-significant effects on the seedling vigour index of stored kenaf seed. Also, the interaction effects of storage location and storage duration on viability, field emergence and seedling vigour index were significant. The interactions of location and variety, as well as storage duration and variety were highly significant $(\mathrm{P} \leq 0.01)$ on seed viability, field emergence and seedling vigour index. The three way interaction effects of location, storage duration and variety were highly significant $(\mathrm{P} \leq 0.01)$ on the three seed quality traits examined. 
Summary of analysis of variance for the seed viability and vigour evaluated under two storage locations and eight storage periods in four kenaf varieties

\begin{tabular}{lccc}
\hline \multicolumn{1}{c}{ Source of variation } & DF & Seed viability $(\%)$ & Seedling vigour index \\
\hline Replication & 2 & $29.57^{\mathrm{ns}}$ & $13.72^{\mathrm{ns}}$ \\
Location (L) & 1 & $462.52^{* *}$ & $7.20^{\mathrm{ns}}$ \\
Storage period (S) & 7 & $4273.18^{* *}$ & $2624.13^{* *}$ \\
Variety (V) & 3 & $314.59^{* *}$ & $18.99^{\mathrm{ns}}$ \\
$\mathrm{L} \times \mathrm{S}$ & 7 & $19.44^{\mathrm{ns}}$ & $38.20^{* *}$ \\
$\mathrm{~L} \times \mathrm{V}$ & 3 & $461.31^{* *}$ & $37.11^{* *}$ \\
$\mathrm{~S} \times \mathrm{V}$ & 21 & $68.74^{* *}$ & $36.22^{* *}$ \\
$\mathrm{~L} \times \mathrm{S} \times \mathrm{V}$ & 21 & $128.39^{* *}$ & $28.44^{* *}$ \\
Error & 126 & 16.73 & 10.26 \\
\hline
\end{tabular}

** Significant at $1 \%$ level of probability; ns- not significant

Results of seed viability tests of four kenaf varieties stored in two storage locations for 240 days under ambient conditions are presented in Table 2 . Differences in varieties response to the storage locations were apparent. At 30 days of storage, Ifeken 400 seeds stored in Ibadan location retained the highest viability value of $83 \%$ compared to other varieties, closely followed by Tianung seeds stored in Abeokuta (77\%) and Ifeken 100 seeds stored in Ibadan location (75\%). However, at 60 days of storage, Ifeken 400 seeds stored in Ibadan location had highest seed viability value of $73 \%$ as well as Ifeken 100 seeds stored in Abeokuta location. Tianung and Ifeken 400 seeds stored at Abeokuta and Ibadan locations, respectively, recorded the highest seed viability data above other varieties at 90 days of storage. At 120 and 150 days of storage, Ifeken 400 seeds stored in Ibadan location recorded the highest seed viability ( $62 \%$ and $59 \%$,) though was similar to viability values retained with Ifeken 100 seeds in Ibadan location (61\%), Tianung and Ifeken 400 seeds in Abeokuta location (61\%). At the end of 180 and 210 days of storage, seeds of Ifeken 400 stored in Ibadan location had the highest seed viability of 58 and $53 \%$, respectively whereas after 240 days of storage, there was a sharp decline in seed viability to less than $50 \%$, irrespective of storage location and variety. Two varieties (Ifeken 400 (43\%) and Tianung (40\%) stored in Ibadan location had the highest viability at the end of storage (240 days). 
Results of viability tests of four kenaf varieties stored in two storage locations for 240 days under ambient conditions

\begin{tabular}{|c|c|c|c|c|c|c|c|c|c|}
\hline \multirow{2}{*}{ Variety } & \multirow{2}{*}{$\begin{array}{l}\text { Storage } \\
\text { location }\end{array}$} & \multicolumn{8}{|c|}{ Storage duration [days] } \\
\hline & & 30 & 60 & 90 & 120 & 150 & 180 & 210 & 240 \\
\hline \multirow{2}{*}{ Ifeken 100} & Abeokuta & $70^{\mathrm{c}}$ & $69^{\mathrm{ab}}$ & $55^{\mathrm{c}}$ & $49^{c}$ & $47^{\mathrm{c}}$ & $45^{\mathrm{cd}}$ & $39^{c}$ & $33^{b}$ \\
\hline & Ibadan & $75^{\mathrm{b}}$ & $65^{\mathrm{bc}}$ & $62^{\mathrm{b}}$ & $61^{\mathrm{ab}}$ & $51^{\mathrm{bc}}$ & $47^{\mathrm{c}}$ & $23^{d}$ & $19^{c}$ \\
\hline \multirow{2}{*}{ Cuba 108} & Abeokuta & $69^{c}$ & $62^{c}$ & $61^{\mathrm{b}}$ & $57^{b}$ & $54^{\mathrm{b}}$ & $52^{\mathrm{b}}$ & $45^{b}$ & $36^{\mathrm{b}}$ \\
\hline & Ibadan & $68^{\mathrm{c}}$ & $63^{c}$ & $60^{\mathrm{b}}$ & $56^{\mathrm{b}}$ & $51^{\mathrm{bc}}$ & $50^{\mathrm{b}}$ & $48^{\mathrm{b}}$ & $26^{\mathrm{c}}$ \\
\hline \multirow{2}{*}{ Tianung } & Abeokuta & $77^{\mathrm{b}}$ & $68^{b}$ & $67^{\mathrm{a}}$ & $61^{\mathrm{ab}}$ & $49^{\mathrm{bc}}$ & $41^{\mathrm{d}}$ & $38^{\mathrm{c}}$ & $34^{\mathrm{b}}$ \\
\hline & Ibadan & $70^{\mathrm{c}}$ & $63^{\mathrm{c}}$ & $60^{\mathrm{b}}$ & $58^{\mathrm{ab}}$ & $58^{\mathrm{ab}}$ & $51^{\mathrm{b}}$ & $48^{\mathrm{b}}$ & $47^{\mathrm{a}}$ \\
\hline \multirow{2}{*}{ Ifeken 400} & Abeokuta & $67^{\mathrm{c}}$ & $62^{\mathrm{c}}$ & $61^{\mathrm{b}}$ & $60^{\mathrm{ab}}$ & $57^{\mathrm{ab}}$ & $47^{\mathrm{h}}$ & $26^{\mathrm{d}}$ & $22^{c}$ \\
\hline & Ibadan & $83^{\mathrm{a}}$ & $73^{\mathrm{a}}$ & $67^{\mathrm{a}}$ & $62^{\mathrm{a}}$ & $59^{\mathrm{a}}$ & $58^{\mathrm{a}}$ & $53^{\mathrm{a}}$ & $43^{\mathrm{a}}$ \\
\hline
\end{tabular}

Mean followed by the same letter along the same column are not significantly different from one another at $5 \%$ level of probability

Table 3 shows the results of seedling vigour tests of four kenaf varieties stored in two storage locations for 240 days under ambient conditions. At 30 days of storage, it was clearly revealed that seed lots of Ifeken 400 stored at the two locations retained the highest seedling vigour index of 37.00 , though not significantly different from seedling vigour value of Ifeken 100 seed lot stored in Ibadan (36.00). However, at 60 days of storage, Ifeken 400 seeds stored in Ibadan and Tianung seeds stored Abeokuta retained highest seedling vigour of 35 and 34, respectively, closely followed by Cuba 108 and Ifeken 100 seeds stored in Abeokuta location. Cuba 108 and Ifeken 400 seeds stored in Abeokuta and Ibadan, respectively, gave the highest seedling vigour values above other varieties at 90 days of storage. After 120 days of storage, Cuba108 and Tianung seeds stored at Abeokuta and Ibadan, respectively recorded highest seedling vigour values. At 150 and 180 days of storage, Cuba 108 seeds stored in Ibadan consistently recorded highest seedling vigour value of 23 and 18, respectively. By 210 days of storage, Cuba108 and Ifeken 100 seeds stored in Abeokuta gave significantly highest seedling vigour index of 13 and 12 above other varieties. Similarly, after 240 days of storage, Tianung, Ifeken 100 and Cuba 108 seeds stored in Abeokuta recorded highest seedling vigour of 7.00, 6.00 and 6.00 , respectively. 
Results of seedling vigour tests of four kenaf varieties stored in two storage locations for 240 days under ambient conditions

\begin{tabular}{ccccccccccc}
\hline \multirow{2}{*}{ Variety } & $\begin{array}{c}\text { Storage } \\
\text { location }\end{array}$ & 0 & 30 & 60 & 90 & 120 & 150 & 180 & 210 & 240 \\
\cline { 3 - 9 } & Abeokuta & $73^{\mathrm{b}}$ & $70^{\mathrm{c}}$ & $69^{\mathrm{ab}}$ & $55^{\mathrm{c}}$ & $49^{\mathrm{c}}$ & $47^{\mathrm{c}}$ & $45^{\mathrm{cd}}$ & $39^{\mathrm{c}}$ & $33^{\mathrm{b}}$ \\
\hline \multirow{2}{*}{ Ifeken 100 } & Ibadan & $76^{\mathrm{ab}}$ & $75^{\mathrm{b}}$ & $65^{\mathrm{bc}}$ & $62^{\mathrm{b}}$ & $61^{\mathrm{ab}}$ & $51^{\mathrm{bc}}$ & $47^{\mathrm{c}}$ & $23^{\mathrm{d}}$ & $19^{\mathrm{c}}$ \\
& Abeokuta & $74^{\mathrm{b}}$ & $69^{\mathrm{c}}$ & $62^{\mathrm{c}}$ & $61^{\mathrm{b}}$ & $57^{\mathrm{b}}$ & $54^{\mathrm{b}}$ & $52^{\mathrm{b}}$ & $45^{\mathrm{b}}$ & $36^{\mathrm{b}}$ \\
Cuba 108 & Ibadan & $75^{\mathrm{b}}$ & $68^{\mathrm{c}}$ & $63^{\mathrm{c}}$ & $60^{\mathrm{b}}$ & $56^{\mathrm{b}}$ & $51^{\mathrm{bc}}$ & $50^{\mathrm{b}}$ & $48^{\mathrm{b}}$ & $26^{\mathrm{c}}$ \\
& Abeokuta & $80^{\mathrm{a}}$ & $77^{\mathrm{b}}$ & $68^{\mathrm{b}}$ & $67^{\mathrm{a}}$ & $61^{\mathrm{ab}}$ & $49^{\mathrm{bc}}$ & $41^{\mathrm{d}}$ & $38^{\mathrm{c}}$ & $34^{\mathrm{b}}$ \\
& Ibadan & $73^{\mathrm{b}}$ & $70^{\mathrm{c}}$ & $63^{\mathrm{c}}$ & $60^{\mathrm{b}}$ & $58^{\mathrm{ab}}$ & $58^{\mathrm{ab}}$ & $51^{\mathrm{b}}$ & $48^{\mathrm{b}}$ & $47^{\mathrm{a}}$ \\
& Abeokuta & $71^{\mathrm{b}}$ & $67^{\mathrm{c}}$ & $62^{\mathrm{c}}$ & $61^{\mathrm{b}}$ & $60^{\mathrm{ab}}$ & $57^{\mathrm{ab}}$ & $47^{\mathrm{h}}$ & $26^{\mathrm{d}}$ & $22^{\mathrm{c}}$
\end{tabular}

Means followed by the same letter along the same column are not significantly different from one another at $5 \%$ level of probability

Table 4 shows the results of PROBIT analysis for the kenaf seed viability (longevity) data after storage in two locations under ambient conditions. The PROBIT programme gave values of intercepts, slopes and half life $\left(P_{50}\right)$ while the storage life values in months were calculated. The values of intercept estimates of initial PROBIT viability and measure of seed viability before storage were generally higher in all locations for each of the varieties except with Ifeken 100 at Ibadan location. This corroborates the actual seed viability before storage of seed lots. The result also shows the negative values of estimates of slope of the seed viability data for all the seed lots, revealing a certain degree of deterioration in the seed lots, irrespective of variety and storage location. On the magnitude of negative slope values, Ifeken 100 and Cuba 108 stored in Ibadan location and Ifeken 400 stored in Abeokuta location recorded significant higher rates of deterioration than other seed lots. However, significant lower rates of seed deterioration were showed by Tianung and Ifeken 400 stored in Ibadan location. It must be noted from Table 2, that percentages seed viability of Tianung and Ifeken 400 were significantly higher over other seed lots at each storage period in Ibadan location. On the half life $\left(P_{50}\right)$ and storage shelf life estimates, Ifeken 400 and Tianung seeds stored in Ibadan location recorded the highest $P_{50}$ value of 140 days and storage shelf life of 9.32 and 9.33 months, respectively compared to other seed lots. Seeds of Cuba 108, Tianung and Ifeken 400 stored in Abeokuta location, as well as Cuba 108 and Ifeken 400 stored in Ibadan location gave a storage shelf life of above 7 
months. However, Ifeken 100 seed stored in both locations had the lowest storage shelf life of between 5.80 and 6.00 months.

Table 4

Result of PROBIT analysis for the kenaf seed shelf life (longevity) data after storage in two locations under ambient conditions

\begin{tabular}{|c|c|c|c|c|c|c|c|}
\hline Variety & $\begin{array}{l}\text { Storage loca- } \\
\text { tion }\end{array}$ & $\begin{array}{c}\text { *Intercept } \\
\text { (Probit viability) }\end{array}$ & & Slope & $\begin{array}{c}\mathrm{P}_{50} \text { Half life } \\
\text { [days] }\end{array}$ & & $\begin{array}{l}\text { helf life } \\
\text { onth] }\end{array}$ \\
\hline \multirow{2}{*}{ Ifeken 100} & Abeokuta & 0.130 & -1.155 & $(0.136)$ & 90 & 6.00 & $(0.026)$ \\
\hline & Ibadan & 0.083 & -1.451 & $(0.153)$ & 87 & 5.80 & $(0.030)$ \\
\hline \multirow{2}{*}{ Cuba 108} & Abeokuta & 0.142 & -1.330 & $(0.136)$ & 106 & 7.07 & $(0.026)$ \\
\hline & Ibadan & 0.133 & -1.556 & $(0.148)$ & 105 & 7.01 & $(0.028)$ \\
\hline \multirow{2}{*}{ Tianung } & Abeokuta & 0.121 & -1.236 & $(0.136)$ & 114 & 7.57 & $(0.028)$ \\
\hline & Ibadan & 0.142 & -1.063 & $(0.123)$ & 140 & 9.32 & $(0.025)$ \\
\hline \multirow{2}{*}{ Ifeken 400} & Abeokuta & 0.101 & -1.452 & $(0.149)$ & 115 & 7.67 & $(0.029)$ \\
\hline & Ibadan & 0.125 & -1.040 & $(0.129)$ & 140 & 9.33 & $(0.025)$ \\
\hline
\end{tabular}

* Intercept is probit estimates of initial seed viability

** $\quad$ Slope is the rate of seed deterioration $(1 / 5)$, probit viability loss per day

*** Seed shelf life was estimated as half life $\left(\mathrm{P}_{50}\right)$ value multiplied by 2 then divided by the 30 days of a month.

Standard errors of the means are in parenthesis

\section{DISCUSSION}

Several authorities in the field of seed science have identified seed viability and seedling vigour index as components of any assessment of seed quality. In the present study, considerable variation occurred among varieties, storage durations and between storage locations for seed viability and seedling vigour index of kenaf. The result also showed that variety, storage location and duration interacted to induce considerable variation in seed viability and seedling vigour index. The significant differences observed among the varieties were mostly due to genetic make-up of the varieties considered, suggesting that there is an opportunity for selection of variety with superior seed quality performance. This view was supported by Adebisi and Ajala, (2000), Kehinde et al. (2005) and Ola, (2008) who observed differences in seed quality of tropical soybean, West African Okra and sesame varieties respectively.

Kenaf seed undergoes various modifications during growth, development, maturation and storage. Therefore, deterioration, a progressive process of ageing, cannot be overlooked, though its speeds differ among seed lots (Ola, 2008). With respect to storage location, Ibadan location provided 
a more favourable storage conditions (with average temperature of $27.5^{\circ} \mathrm{C}$ and relative humidity of $64.68 \%$ ) for higher seed viability and seedling vigour index compared to Abeokuta location (with average temperature of $29.8^{\circ} \mathrm{C}$ and relative humidity of $59.10 \%$ ). It was revealed from the study that kenaf seeds differed in their seed viability response to period of storage, indicating varietal differences in kenaf when under storage. Seed viability response, irrespective of variety, gradually declined with increase in storage days and Ifeken 400 had a distinct peak of seed viability, probably due to genetic make-up, closely followed by Tianung. A sharp decline in viability after 180 days was observed suggesting that kenaf seed storage under ambient conditions should not exceed 180 days (6 months) for the maintenance of maximum seed viability, irrespective of storage location.

Kenaf seed, being high in oil content, has problem with its storage and vigour deterioration will be comparatively high. This study showed that as storage days increased seedling vigour index of varieties was found to decline due to the effect of intrinsic deterioration process enhanced by the ambient storage conditions. Variations occurred in seedling vigour index among the kenaf varieties at each of the storage days. Superior seedling vigour was obtained at 120 days of storage with Cuba108, followed by Tianung and Ifeken 100. However, the varieties still had considerable high vigour quality at 180 days of storage. Therefore, storage period for the kenaf varieties should not exceed 180 days in order to maintain high seedling vigour as well as seed viability and field emergence under ambient conditions, irrespective of storage location. However, it is interesting to note that seeds of Ifeken 400 and Tianung stored in Ibadan location had the highest viability at the end of the storage (240 days) with moderately high seedling vigour.

The result of the PROBIT modelling of seed longevity of kenaf seeds stored in the two locations revealed differences in estimates of intercepts and slopes, indicating significant reduction in seed longevity of kenaf, irrespective of storage duration examined. Reports of variety and seed lot differences in potential seed longevity among varieties of different species were reported by Zanakis et al., (1993); Raheem, (2006) and Adebisi et al., 2008). This result may not conclude superiority in seed longevity among the varieties since the seed intercept attribute is a seed lot parameter as reported by Ellis and Roberts (1980) but confirmed that seed deterioration rate and eventual seed storage life is dependent on the initial viability of seed moved into storage. Demir and Ellis (1992), Zanakis et al., (1993) and Adebisi et al., (2008) have pointed out in their works that the higher the quality of a seed put into storage, the longer the expected seed shelf life. In this study, Tianung and Ifeken 400 seed lots stored under ambient conditions in Ibadan location showed significant longest storage life than other seed lots. However, other seed lots stored in either Abeokuta or 
Ibadan showed storage life of 7 months and above except seed lot of Ifeken 100 stored in Ibadan or Abeokuta location which had a storage life of 6 months.

In conclusion, when preserving kenaf seeds, consideration should be given to the storage location, variety and storage duration. Kenaf seeds should be properly stored in order to reduce the level of deterioration and enhance higher seed quality. Kenaf seeds could be stored for up to six months before planting in ambient storage conditions and still maintain higher physiological quality with little or no cost. Two varieties, Ifeken 400 and Tianung, had superior storage potential over two other varieties. The PROBIT model result revealed that Tianung and Ifeken 400 seed lots stored under ambient conditions in Ibadan location showed significant longest storage shelf life ( 9 months) than other seed lots.

\section{REFERENCES}

Adebisi, M. A. Daniel, I. O., Ajala, M.O. 2003. Storage life of soybean seed after seed dressing. J. of Trop. Agric. (India) 42: 37.

Adebisi, M. A., Akintobi, D. C. and Oyekale, K. O. 2008. Preservation of okra seed vigour by seed treatments and storage containers. Nigerian Journal of Horticultural Science. 12:1-7.

Adebisi, M. A., Ajala, M. O., Ariyo, O. J. 2004. Genetic studies on seed quality in sesame. Proceedings of the 29th Annual conference of the Genetics Society of Nigeria. pp 209-212.

Adebisi, M.A. 2004. Variation, stability and correlation studies in seed quality and yield components of sesame (Sesamum indicum L). PhD Thesis, University of Agriculture, Abeokuta, Nigeria.

Aimin, R. I. 2006. Making pulp and paper from kenaf, On the internet file://D:/Kenaf modules. php .htm.

Akintobi , D. C, Adebisi, M. A, Ola, J. A. 2006. Effects of storage conditions and period of storage on the maintenance of seed quality of sesame. Asset Series A 6: (2) : 275-285.

Demir, I., Ellis, R. H. 1992. Development of pepper (Capsicum annum) seed quality. Ann. Appl. Bot., 121: $385-399$.

Duncan, D. B. 1955. Multiple Range and Multiple F-tests. Biometrics II: $1-42$.

Ellis, R. H. and Roberts, E. H. 1980. Improved Equation for the Prediction of Seed longevity. Annals of Botany, 45: 13-30.

Greg, B. Wanus, S. A. E., Bishaw, Z. and Van-Caste A. J. G. 1994. Safe seed storage WANPA Seed Network Publication No. 5/4 ICARDA Aleppo. Syria.

Harrington. J. F. 1972. Seed and pollen storage for the conservation of plant gene resources, pp. $510-$ 521. In Franked, H.O. Benneh (eds) Genetic England 554.

Kim, S. H, Choe, Z. R., Kang, J. H., Copeland, L. O. and Elias, S. G. 1994. Multiple seed vigour indices to predict field emergence and performance of barley. Seed Science and Technology 22:2938.

Nkang, A., Umoh, E. O.1996. Six months storability of five soybean cultivars as influenced by stage of harvest, storage temperature and relative humidity. Seed Science and Technol. 25:93-99

Ola, A. J .2008. Effect of storage locations and container types on quality of sesame (Sesame indicum) seeds. Master of Agric. Dissertation. University of

Agriculture, Abeokuta, Nigeria.71p.

Raheem, A. 2006 .Seed invigoration treatments for improved germination and seedling

vigour of stored okra seeds. B.Agric Project. Department of Plant Breeding and Seed Technology, University of Agriculture, Abeokuta, Nigeria. 36p.

Roberts, E. H. 1973. Predicting the storage life of seeds. Seed Science and Technology 499-522.

Roberts, E. H. 1983. Storage environment and the control of viability of seeds .E.H.

Roberts (eds)Pg14-58.Chapman and Hall, London. 
Thseng, F.S; Hon, F. F; Wu, S. T. 1996. Varieted Differences in germination rate, storability and flooding tolerance of soyabean seed produced from different cultural seasons and locations. Japanese Journal of Crop Science, 65, 525-531.

Zanakis, G. N, Ellis, R. H, Summerfield, R. J. 1993. Response of seed longevity to moisture content in three genotype of soybean (Glycine max).Exptl. Agric. 29, 449-459. 